\title{
Characterization of Antiseptic Apatite Powders Prepared at Biomimetics Temperature and pH
}

\author{
Soumia Belouafa ${ }^{\mathrm{a}}$,Hassan Chaair ${ }^{\mathrm{a} *}$, Hayate Loukili $^{\mathrm{b}}$, Khalid Digua ${ }^{\mathrm{a}}$, Brahim Sallek $^{c}$ \\ a'Laboratoire de Génie des Procédés et de Dépollution, \\ Facultés des Sciences et Techniques de Mohammedia, B. P. 146, Mohammedia 20 800, Morocco \\ ${ }^{\mathrm{b}}$ Laboratoire des Matériaux, Catalyse et Environnement, \\ Facultés des Sciences et Techniques de Mohammedia, Morocco \\ 'Laboratoire de Génie des Procédés, Faculté des Sciences de Kenitra, Morocco
}

Received: October 28, 2007; Revised: March 4, 2008

\begin{abstract}
Antiseptic apatite-based calcium phosphates were prepared as the single-phase powders. Phosphocalcic oxygenated apatites were synthesized from calcium salts and orthophosphate dissolved in oxygenated water solution at $30 \%$, under the biomimetic conditions of $37^{\circ} \mathrm{C}$ and $\mathrm{pH} 7.4$. The characterization and chemical analysis of the synthesized biomimetic apatite powders were performed by scanning electron microscopy (SEM), powder $\mathrm{X}$ ray diffraction (XRD), Fourier-transformed infrared spectroscopy (FT-IR) and chemical analysis. The obtained materials are a calcium deficient apatites with different morphologies.
\end{abstract}

Keywords: calcium phosphate, oxygenated apatite, precipitation, biomimetic conditions

\section{Introduction}

Phosphocalcic oxygenated apatites are among the most promising calcium phosphate apatites because of there antiseptic properties which make them able of limiting the proliferation of micro-organisms at the site of implantation ${ }^{1}$. These properties are due to the oxygenated species (peroxide ions: $\mathrm{O}_{2}{ }^{2-}$ and/or molecular oxygen: $\mathrm{O}_{2}$ ) contained in the channels of the apatitic structure ${ }^{1,2}$. These species were liberated in the living environment either by progressive dissolution of the material, or by chemical exchange with the living environment ${ }^{1}$. The peroxide ions thus liberated act in situ to destroy the micro-organisms with a well known effectiveness for these species ${ }^{1}$. The molecular oxygen acts in a specific manner on anaerobic micro-organisms while locally increasing the partial pressure of oxygen ${ }^{1}$.

Phosphocalcic oxygenated apatite powders have generally been synthesized by using aqueous solutions ${ }^{1-6}$.

In this study, phosphocalcic oxygenated apatite powders were prepared at the physiological conditions of $\mathrm{pH} 7.4$ and $37^{\circ} \mathrm{C}$ using calcium salts and phosphoric acid as $\mathrm{Ca}$ and $\mathrm{P}$ precursors. Their characteristic were discussed and compared.

\section{Experimental}

The preparation of phosphocalcic oxygenated apatites were performed by precipitation reaction with calcium and phosphate solutions:

The calcium solution (1 M) was prepared by dissolution of calcium salt $\left(\mathrm{CaCO}_{3}, \mathrm{Ca}\left(\mathrm{NO}_{3}\right)_{2}\right.$ or $\left.\mathrm{CaCl}_{2}\right)$ in oxygenated water $(30 \%)$.

The phosphate solution $(0.6 \mathrm{M})$ was prepared by adding phosphoric acid $(84 \%)$ in oxygenated water $(30 \%)$.

The synthesis method consists in putting the calcium solution into $1 \mathrm{~L}$ capacity reactor maintained at $37{ }^{\circ} \mathrm{C}$. The $\mathrm{pH}$ was adjusted to 7.4 by manual addition of $\mathrm{NH}_{4} \mathrm{OH}$ solution $(\mathrm{d}=0.92)$. Then the phosphoric acid solution was poured into the reactor all at once. The reacting medium was kept under agitation for 4 hours at the $\mathrm{pH}$ value of 7.4. At the end, the suspension was vacuum filtered, washed with distilled water and air dried.
$\mathrm{X}$ ray diffraction analysis was carried out by means of a SEIFERT XRD $3000 \mathrm{P}$ using CuK radiation.

For infrared absorption analysis, $1 \mathrm{mg}$ of the powered samples was carefully mixed with $300 \mathrm{mg}$ of $\mathrm{KBr}$ and palletised under vacuum. The pallets were analysed using a Perkin Elmer 1600 FTIR spectrophotometer.

Scanning electron microscopy was used for morphological investigation by means of SEM, Cambridge 360 .

Calcium, phosphorus and oxygenated species contents were determined by wet chemical methods:

Calcium was titrated by complexometry ${ }^{7}$. The error on the calcium content is around $0.5 \%$.

Phosphorus content was analysed by colorimetry ${ }^{8}$. The accuracy of this dosage was determined with a relative error of $0.5 \%$.

Molecular oxygen was determined by measuring the volume displaced during the acid dissolution of powder Using asbestos sodé to adsorb the $\mathrm{CO}_{2}$ released ${ }^{1}$. The same dosage was achieved without using asbestos sodé; the quantity in carbonate ions is determined by the difference between the two volumes. Uncertainty in these dosage is about $2 \%$.

Peroxide ions were titrated by manganimetry 9 . The relative error on this dosage is approximately $1 \%$.

\section{Results and Discussion}

The prepared material presents a yellowish colouring characteristic of phosphocalcic oxygenated apatites ${ }^{3,10,11}$.

The $\mathrm{X}$ ray diffraction data of as-dried powder (Figure 1) shows its poor crystallinity. Its diffractogram closely resembles that of bone ${ }^{12,13}$.

The infrared spectra (Figure 2) confirm the presence of $\mathrm{PO}_{4}^{3-}\left(1096-1036 \mathrm{~cm}^{-1}\right.$ and 606-562 $\left.\mathrm{cm}^{-1}\right), \mathrm{OH}^{-}\left(3566 \mathrm{~cm}^{-1}\right), \mathrm{H}_{2} \mathrm{O}$ $\left(1640 \mathrm{~cm}^{-1}\right.$ and $\left.3430 \mathrm{~cm}^{-1}\right)$ and $\mathrm{HPO}_{4}{ }^{2-}\left(874 \mathrm{~cm}^{-1}\right)$ which exists in non-stiochiometric hydroxyapatite (HAP) ${ }^{14}$. However, the spectrum of 


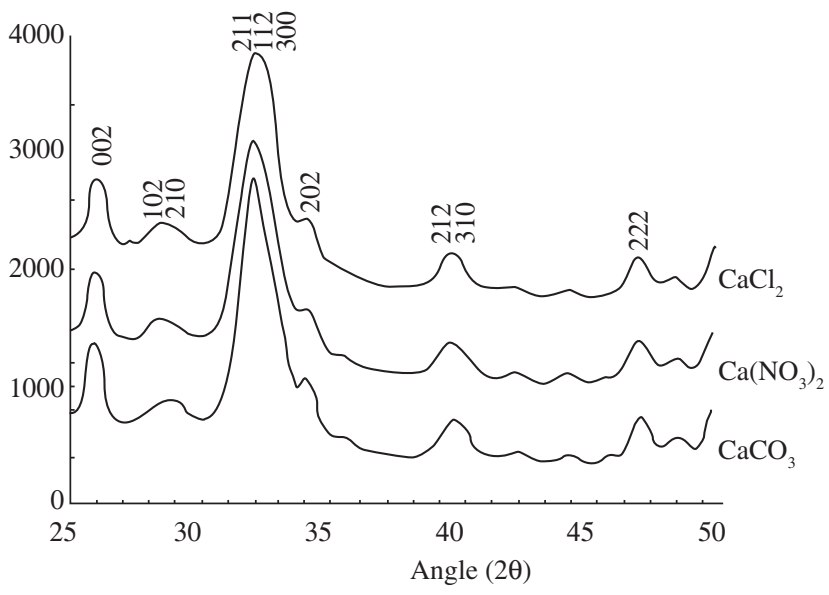

Figure 1. XRD patterns of obtained powders.
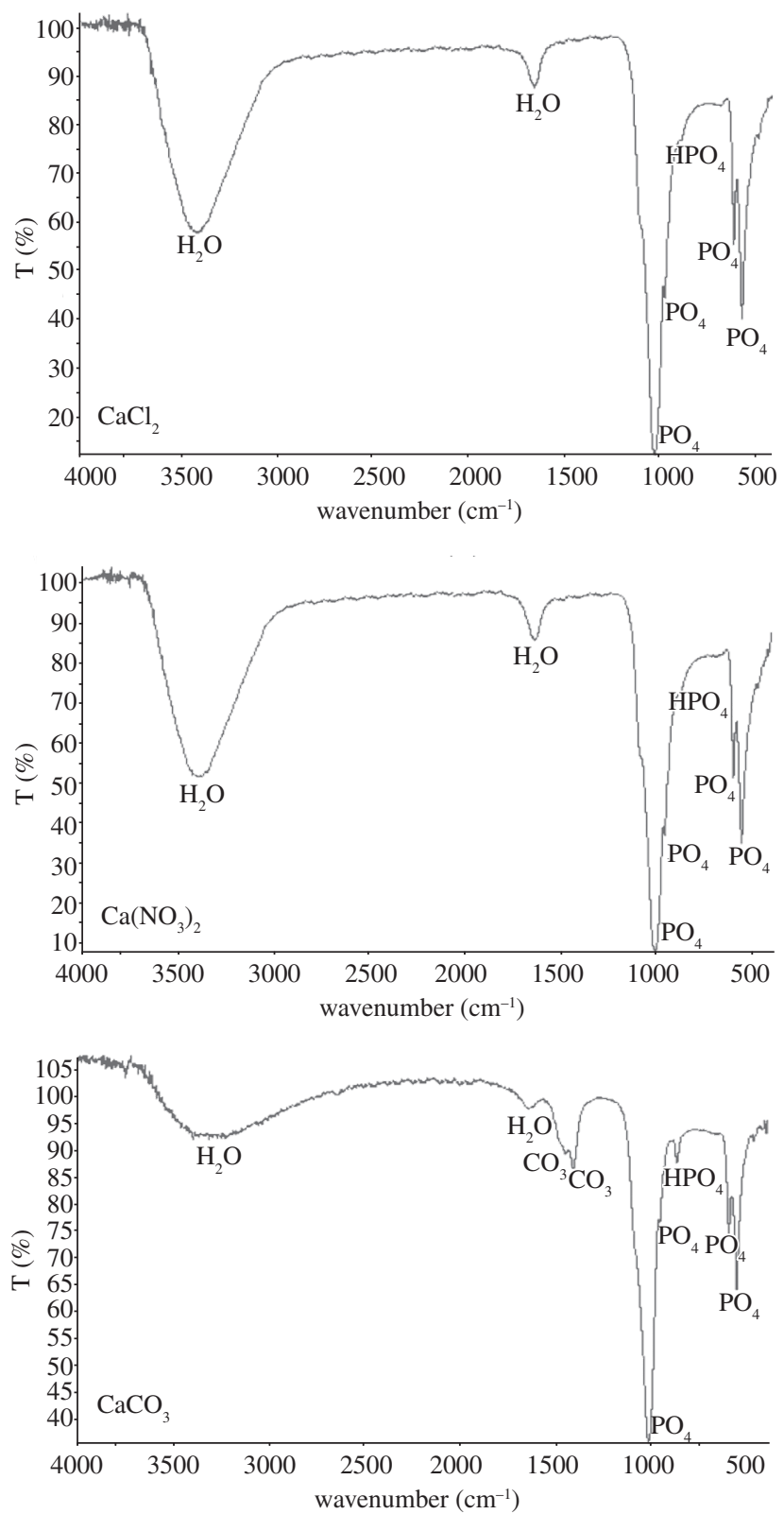

Figure 2. FT-IR spectra of obtained powders. oxygenated apatite prepared from $\mathrm{CaCO}_{3}$ present of the bands ascribable to the carbonate ions $\mathrm{CO}_{3}{ }^{2-}\left(1412\right.$ and $\left.1465 \mathrm{~cm}^{-1}\right)$ which do not disappear after calcination of this apatite at $900{ }^{\circ} \mathrm{C}$ for 2 hours (Figure 3). This proves that these carbonate ions are of type B15. These ions can be to come only from calcium carbonate used like calcium precursor. The Figure 3 shows yet the absorption band corresponding to the $\mathrm{OH}^{-}$vibrationnelle mode $\left(3566 \mathrm{~cm}^{-1}\right)$ and the $\mathrm{OH}^{-}$bending deformation mode $\left(633 \mathrm{~cm}^{-1}\right)$ which exist in $\mathrm{HAP}^{16}$ and a characteristic band $\left(985 \mathrm{~cm}^{-1}\right)$ of $\beta-\mathrm{TCP}^{15}$. The thermal decomposition reaction has been proposed to occur in according to the reaction observed in the case of non-stiochiometric phosphocalcic $\mathrm{HAP}^{17}$ :

$$
\begin{aligned}
& \mathrm{Ca}_{10-\mathrm{x}}\left(\mathrm{HPO}_{4}\right)_{\mathrm{x}}\left(\mathrm{PO}_{4}\right)_{6-\mathrm{x}}(\mathrm{OH})_{2-\mathrm{x}} \rightarrow \\
& (1-\mathrm{x}) \mathrm{Ca}_{10}\left(\mathrm{PO}_{4}\right)_{6}(\mathrm{OH})_{2}+3 \mathrm{xCa}_{3}\left(\mathrm{PO}_{4}\right)_{2}+\mathrm{xH}_{2} \mathrm{O}
\end{aligned}
$$

The presence of $\mathrm{HAP}^{18}$ and $\beta-\mathrm{TCP}^{19}$ is confirmed by XDR (Figure 4).

The aspect of the synthesized powders suggests the typical apatite appearance as shown in Figure 5. These photomicrographs suggest porous aggregates of particles prepared from $\mathrm{CaCO}_{3}$, very compact grains of particles prepared from $\mathrm{CaCl}_{2}$, intermediate aspect of particles prepared from $\mathrm{Ca}\left(\mathrm{NO}_{3}\right)_{2}$. The porosity of the apatite prepared from the $\mathrm{CaCO}_{3}$ can be due to release of $\mathrm{CO}_{2}$ during the attack acid of $\mathrm{CaCO}_{3}$ by hydrogen peroxide.

The variety of morphological states of these biomaterials broadened their field of biomedical application. As the porous apatites

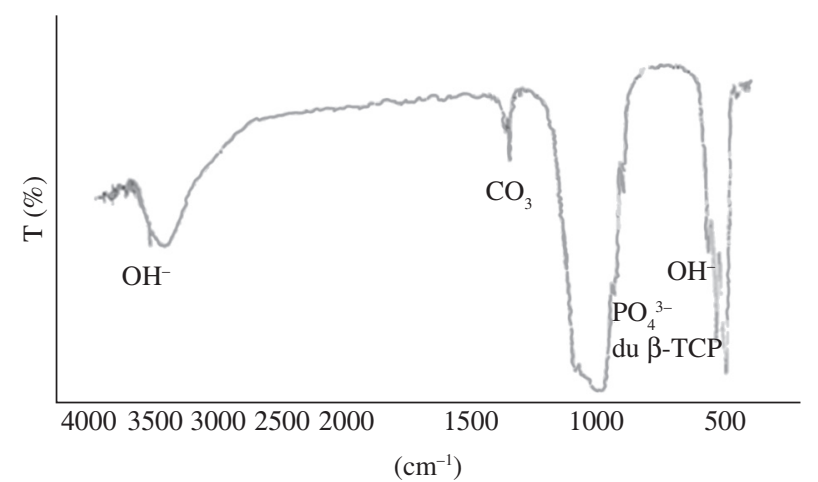

Figure 3. FT-IR spectra of carbonated oxygenated apatite after calcination at $900{ }^{\circ} \mathrm{C}$ for 2 hours.

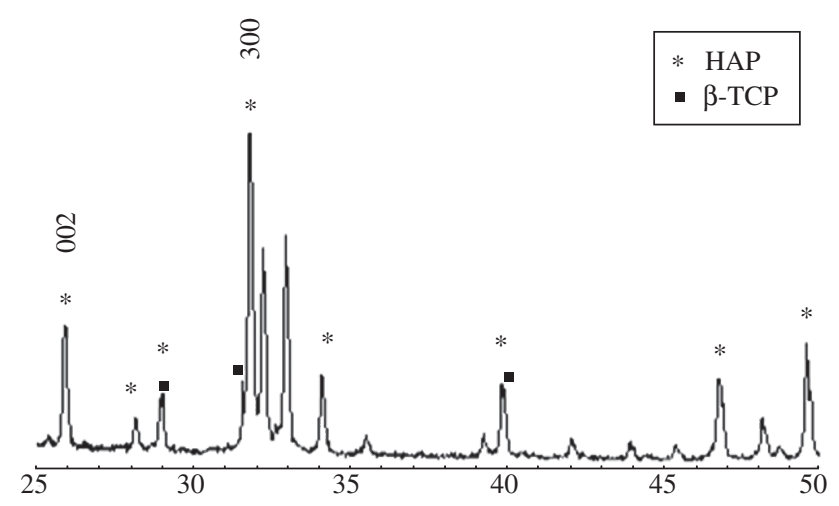

Figure 4. XDR pattern of carbonated oxygenated apatite after calcination at $900{ }^{\circ} \mathrm{C}$ for 2 hours. 


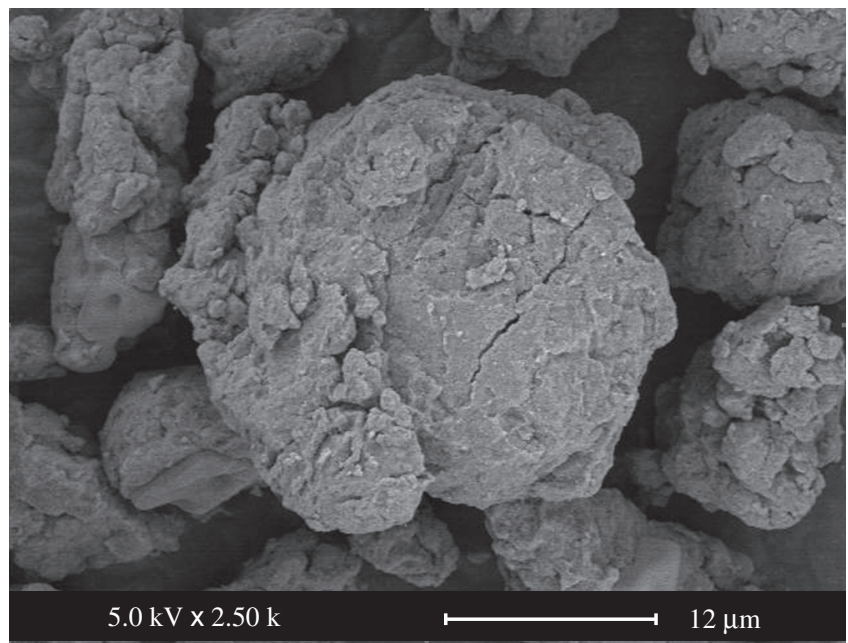

\section{$\mathrm{CaCl}_{2}$}

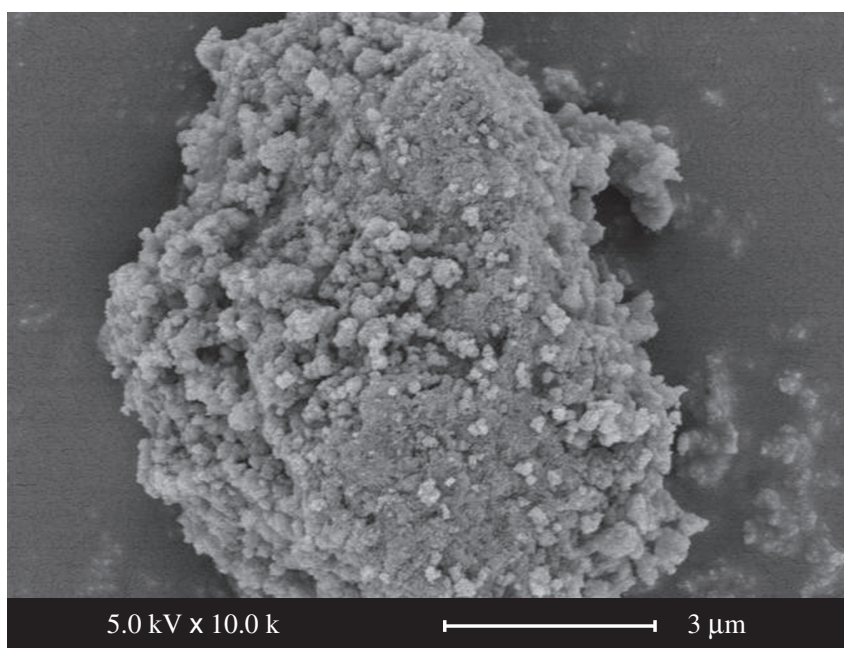

$\mathrm{Ca}\left(\mathrm{NO}_{3}\right)_{2}$

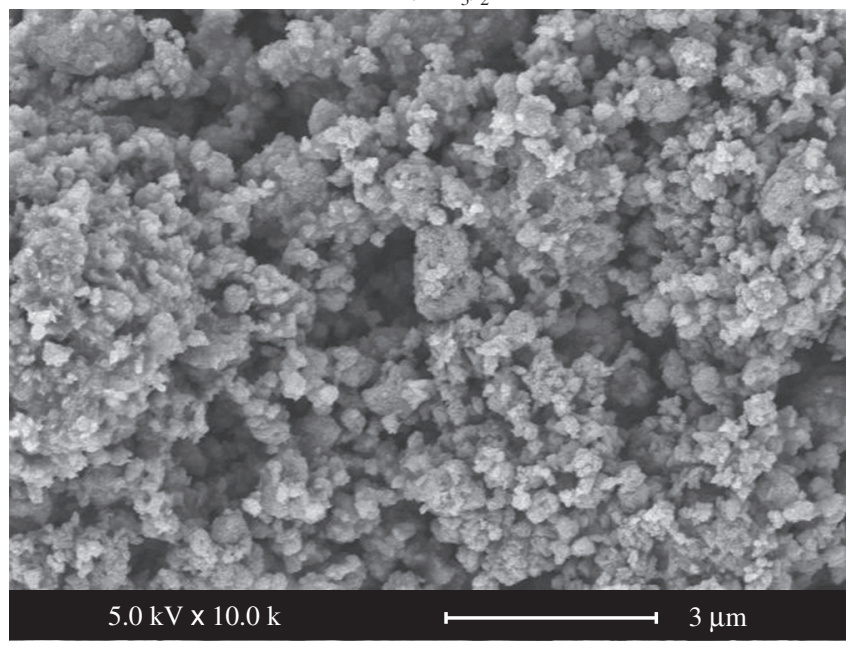

$\mathrm{CaCO}_{3}$

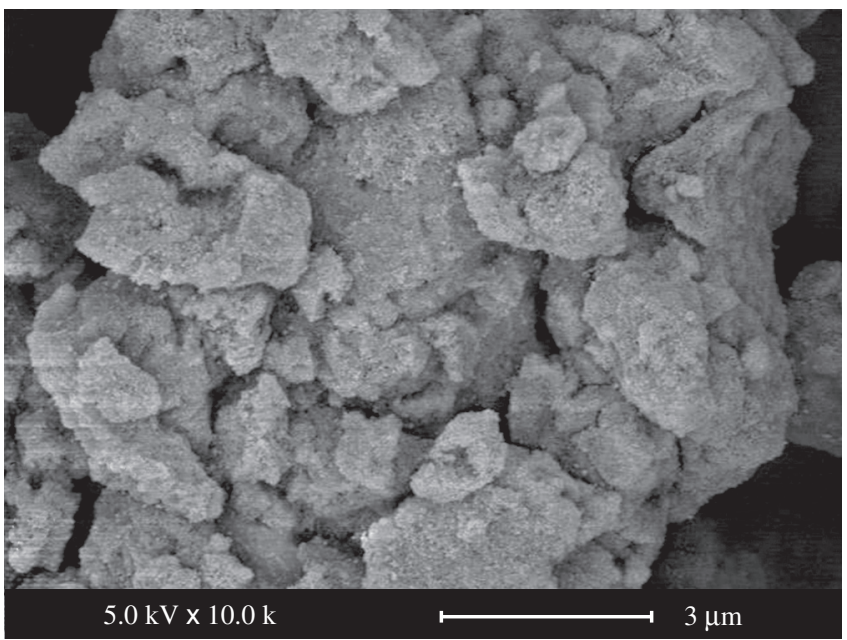

$\mathrm{CaCl}_{2}$

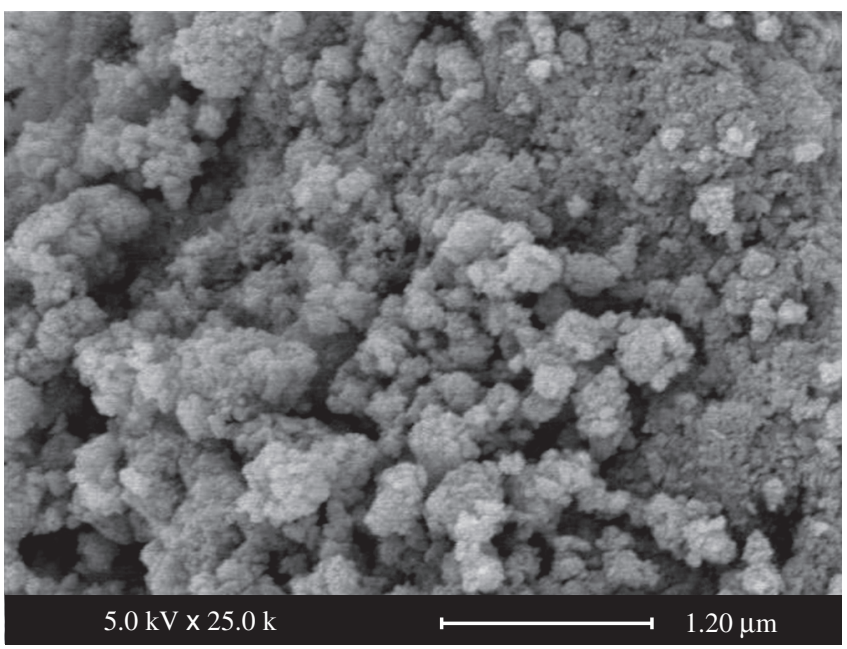

$\mathrm{Ca}\left(\mathrm{NO}_{3}\right)_{2}$

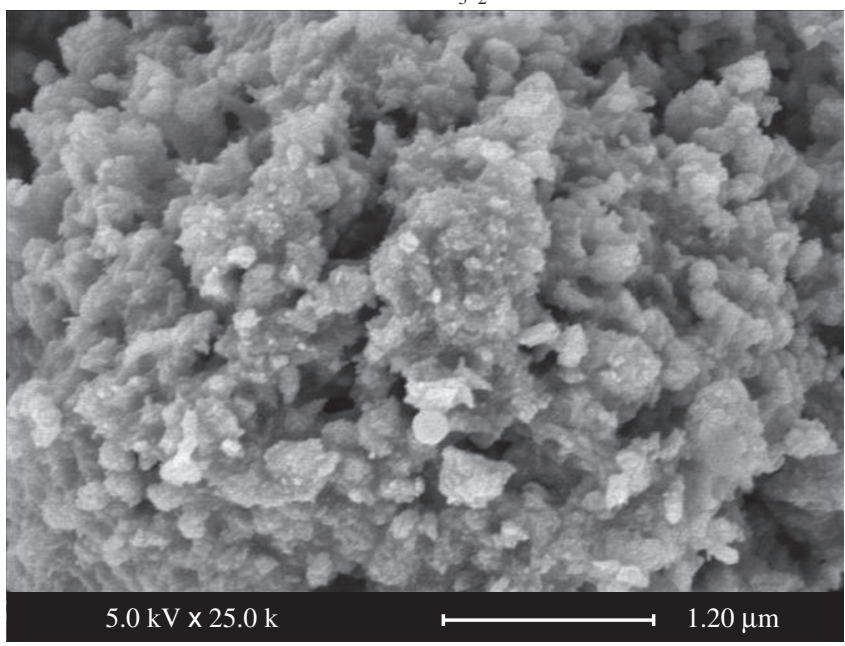

$\mathrm{CaCO}_{3}$

Figure 5. Scanning electron microscopy of as-dried powder.

exhibit strong bonding to the bone; the pores provide a mechanical interlock leading to a firm fixation of the material ${ }^{20}$. Bone tissue grows well into the pores, increasing strength of the apatite implant. It is realized that dimension and morphology of pores are crucial factors for an excellent osteointegraton. As for dense apatite, they are used for the formation of ceramic blocks with different forms and for the recovery of implants ${ }^{21}$.

The chemical analysis (Table 1) shows that the obtained materials are a calcium deficient apatites with $\mathrm{Ca} / \mathrm{P}$ ratio and following chemical formulas: 
Table 1. Results of the chemical analysis of prepared apatites.

\begin{tabular}{ccl}
\hline Starting salts & Obtained Ca/P* & \multicolumn{1}{c}{ Chemical formulas of products* } \\
\hline $\mathrm{CaCO}_{3}$ & 1.59 & $\mathrm{Ca}_{9.27}\left(\mathrm{PO}_{4}\right)_{5.56}\left(\mathrm{HPO}_{4}\right)_{0.29}\left(\mathrm{CO}_{3}\right)_{0.1}(\mathrm{OH})_{0.68}\left(\mathrm{O}_{2}{ }^{2-}\right)_{0.20}\left(\mathrm{O}_{2}\right)_{0.21}$ \\
$\mathrm{Ca}\left(\mathrm{NO}_{3}\right)_{2}$ & 1.60 & $\mathrm{Ca}_{9.57}\left(\mathrm{PO}_{4}\right)_{5.88}\left(\mathrm{HPO}_{4}\right)_{0.12}(\mathrm{OH})_{0.62}\left(\mathrm{O}_{2}{ }^{2-}\right)_{0.32}\left(\mathrm{O}_{2}\right)_{0.44}$ \\
$\mathrm{CaCl}$ & 1.60 & $\mathrm{Ca}_{9.59}\left(\mathrm{PO}_{4}\right)_{5.82}\left(\mathrm{HPO}_{4}\right)_{0.18}(\mathrm{OH})_{0.74}\left(\mathrm{O}_{2}{ }^{2-}\right)_{0.31}\left(\mathrm{O}_{2}\right)_{0.45}$ \\
$*: \Delta(\mathrm{Ca} / \mathrm{P})= \pm 0.01 ; \Delta(\mathrm{Ca})= \pm 0.005 ; \Delta\left(\mathrm{PO}_{4}\right)= \pm 0.005 ; \Delta\left(\mathrm{HPO}_{4}\right)= \pm 0.01 ; \Delta\left(\mathrm{CO}_{3}\right)= \pm 0.02 ; \Delta\left(\mathrm{O}_{2}{ }^{2-}\right)= \pm 0.01 ; \Delta\left(\mathrm{O}_{2}\right)= \pm 0.02$.
\end{tabular}

\section{Conclusions}

Single-phase phosphocalcique oxygenated apatite powders were synthesized by a novel chemical precipitation technic at the physiological conditions of $\mathrm{pH} 7.4$ and $37^{\circ} \mathrm{C}$. The produced powders were shown to have poor crystallinity and various compositions and morphological states what widened their biomedical applicability.

\section{References}

1. Ledard C. Benque E. Lacout JL. Rey C. Biomatériaux de comblement osseux ou dentaire, et procédés de préparation. Patent FR 2652748; 1989.

2. Simpson DR. Substitutions in apatite. I. Potassium-bearing apatite. Am. Mineral. 1968; 53: 432-444.

3. Rey C. Etude des relations entre apatites et composés moléculaires; Thèse d'Etat I.N.P: Toulouse 1984.

4. Belouafa S. Chaair H. Digua K. Sallek B. Mountacer H. Nouveau procède de synthèse d'une apatite carbonatée à caractère antiseptique. Phosphorus, Sulfur and Silicon. 2005; 180: 2679-2687.

5. Belouafa S. Chaair H. Digua K. Oudadesse H. Sallek B. Mountacer H. Utilisation des plans d'experiences pour la modelisation de l'élaboration d'un phosphate de calcium de proprietes antiseptiques à usage biomedical. Phosphorus, Sulfur and Silicon. 2006; 181: 337-349.

6. Belouafa S. Chaair H. Digua K. Sallek B. Essaadani A. Oudadesse H. Synthesis, Characterization and thermal behaviour of a phosphocalcic oxygenated apatite. Journal of Advanced Materials. 2007; 2: 139-142.

7. Meyer JL. Eanes ED. The maturation of crystalline calci-. um phosphates in aqueous suspensions at physiologic pH. Calcified Tissue Res. 1977; 23: 259-269.

8. Gee A. Dietz VR. Determination. of phosphate by differential spectrophotometry. Anal. Chem. 1953; 25: 1320-1324.
9. Trombe JC, Montel G. Some features of the incorporation of. oxygen in different oxidation states in apatite lattice. J. Inorg. Nucl. Chem. 1978; 40: $15-21$

10. Vignoles-Montrejaud, M. Contribution a l'étude des apatites carbonattes de type B. Toulouse, France: These d'Etat, INP; 1984.

11. Trombe JC. Annal. Chim. 1973; 8: 335.

12. LeGeros RZ. Biological and synthetic apatites. In: PW Brown and B. Constantz, Editors, Hydroxyapatite and related materials, CRC Press, Boca Raton. 1994; 3.

13. Peters F. Schwarz K. Epple M. The structure of bone studied with synthrotron X-ray diffraction, X-ray absorption spectroscopy and thermal analysis. Thermochim. Acta. 2000; 361: 131-138.

14. Yubao L. Kelein CPAT. Xingdong Z. de Groot K. Formation of a bone apatite-. Like layer on the surface of porous HA. Ceramics. Biomaterials. 1994; 15: 835-840.

15. El Feki H. Khattech I. Jemal M. and Rey C. Decomposition thermique d'hydroxyapatites carbonatées sodées: Thermal decomposition of carbonated hydroxyapatites containing sodium ion. Thermochimica Acta. 1994; 237: 99-110.

16. Yubao L. Kelein CPAT. Xingdong Z. de Groot K. Formation of a bone apatite-. Like layer on the surface of porous HA. Ceramics. Biomaterials. 1994; 15: 835-840.

17. Destainville A. Champion E. Bernache-Assollant D. Laborde E. Synthesis, characterization and thermal behavior of apatitic tricalcium phosphate. Materials Chemistry and Physics. 2003; 80: 269-277.

18. File $\mathrm{N}^{\circ} 73-0293$. International Center for Diffraction Data, ICDD.

19. File $\mathrm{N}^{\circ} 70-2065$. International Center for Diffraction Data, ICDD.

20. Daculci G. Passuti N. Martin S. Macroporous calcium phosphate ceramic for long bone surgery in humans and dogs. Clinical and histological study. Biomed. Mater. Res. 1990; 24(3): 379-396.

21. Daculci G. Legros J.P. Three-dimensional defects in hydroxyapatite of biological interest. Biomed. Mater. Res., 1996; 4: 495-501. 